GEOPHYSICAL RESEARCH LETTERS, VOL. 17, NO. 2, PAGES 163-166, EEBRUARY 1990

\title{
IVORY COAST MICROTEKTITES AND GEOMAGNETIC REVERSALS
}

\author{
David A. Schneider 1 and Dennis V. Kent \\ Lamont-Doherty Geological Observatory and Department of Geological Sciences, \\ Columbia University, Palisades NY
}

\begin{abstract}
The reported association of the Ivory Coast microtektite occurrence with the onset of the Jaramillo normal polarity subchron has given support to the notion that impact events can give rise to geomagnetic reversals. We re-evaluate the paleomagnetic stratigraphy of two critical deep-sea sediment cores bearing Ivory Coast microtektites (K9-57 and V27-239) and show that this event likely occurred during the Jaramillo subchron approximately $30 \mathrm{kY}$ after its onset and 40 $\mathrm{kY}$ before its termination. This new result thus argues against any causal relationship between the Ivory Coast tektiteproducing event and a geomagnetic polarity reversal.
\end{abstract}

\section{Ivory Coast Microtektites and the Jaramillo Subchron}

Almost 20 years after it was first suggested (Glass and Heezen, 1967), the notion that impacts trigger geomagnetic reversals has been invested with a possible mechanism (Muller and Morris, 1986, 1989). Although the validity of the theory linking an external impact event with changes in the internallyproduced geomagnetic field remains a matter of debate, we deemed it worthwhile to reconsider some of the geologic evidence that such events might be synchronous. In particular, we have reviewed the correlation between the Ivory Coast microtektite occurrence and the onset of the Jaramillo normal polarity subchron that was discussed by Glass et al. (1979) and Glass and Zwart (1979).

Ivory Coast tektites have been tentatively linked to the Pleistocene Bosumtwi impact crater in Ghana (Cohen, 1963; Gentner et al., 1967; Shaw and Wasserburg, 1982). Several deep-sea sediment cores taken from the eastern equatorial Atlantic contain Ivory Coast microtektites and are particularly important because they also provide a magnetostratigraphic record of geomagnetic polarity. Using the magnetostratigraphy derived from such deep-sea sediments, the Ivory Coast microtektites have been associated with the onset of the Jaramillo normal polarity subchon; similarly, microtektites of the Australasian strewnfield have been associated with the Matuyama to Brunhes polarity reversal (Glass et al., 1979).

Although the coincidence of the Australasian tektites with the Matuyama/Brunhes magnetic reversal boundary is supported by more recent detailed study of 39 deep-sea sediment cores (Burns, 1989), the suggested association of Ivory Coast microtektites with the onset of the Jaramillo subchron rests on data from just 5 cores (Glass and Zwart, 1979). Because the original paleomagnetic results from these 5 cores were not particularly straightforward, we decided to reexamine the magnetostratigraphic evidence from critical cores.

1 Now at, Centre des Faibles Radioactivités, Laboratoire Mixte CNRS-CEA, Gif-sur-Yvette, France

Copyright 1990 by the American Geophysical Union.

Paper number 89GL03499.

0094-8276/90/89GL-03499\$03.00

\section{Magnetostratigraphic Results}

\section{Microtektite-Bearing Cores}

The five cores reported by Glass and Zwart (1979) to contain Ivory Coast microtektites are K9-56, K9-57, V19297, V19-300 and V27-239 (Figure 1). According to their results, K9-56 showed only a few microtektites at the base of the core with no clearly defined peak in abundance. This core appears to have penetrated only the topmost sediments of the Jaramillo subchronozone and probably did not sample the actual microtektite horizon. The results of Glass et al. (1979) and Glass and Zwart (1979) for core V19-297 indicated a broadly distributed microtektite horizon and also gave no clear indication of the Jaramillo subchronozone. Because little of the original material from this core was available for further study, and because we anticipated that the interpretation of any magnetostratigraphy would be complicated by many breaks incurred during the core's handling, we did not attempt to restudy this core. Core V19-300 is also described by Glass and Zwart (1979) as containing a poor microtektite record: microtektites are found scattered over a $250 \mathrm{~cm}$ interval, with no clear peak in the abundance profile. Moreover, the magnetostratigraphic results for V19-300, as described by Glass and Zwart (1979), are difficult to interpret below the Brunhes/Matuyama boundary, further suggesting that these sediments were disturbed.

The critical cores thus are K9-57 and V27-239. The original studies of Glass et aI. (1979) and Glass and Zwart (1979) showed a microtektite abundance peak that was virtually coincident with the lowermost Jaramillo normal polarity sediments in core K9-57, and also indicated a welldefined microtektite peak in core V27-239 within the Jaramillo subchronozone, although the base of the Jaramillo was not identified.

\section{Re-examination of K9-57 and V27-239}

We resampled both K9-57 and V27-239 and determined paleomagnetic directions (Figures 2 and 3 ) from the results of standard progressive alternating field demagnetization treatment (taken, typically, to $50 \mathrm{mT}$ ). The results, determined from principal component analysis (Kirschvink, 1980) of the demagnetization data, show stable magnetization directions which generally have shallow inclinations that are consistent with the low latitude of these two equatorial sites $\left(9^{\circ} \mathrm{N}\right.$ for $\mathrm{K} 9-57$ and $8^{\circ} \mathrm{S}$ for V27-239).

Both cores indicate a pattern of polarity reversals that suggests the recovered magnetization directions are indeed primary. Neither of these cores was oriented in azimuth; therefore the declinations can be measured only relative to the split face of the core. (Note that both cores show gradual rotations of declination with depth, most likely reflecting a distributed twist during coring.) In the case of core V 27-239, internal orientation was maintained throughout the various phases of core handling and thus $180^{\circ}$ shifts in declination correspond to actual reversals of polarity. The one anomalous point from V27-239 near $600 \mathrm{~cm}$ is most probably spurious, the sample being located close to a core pipe break where cored sediments are often disturbed. In contrast, internal orientation may not have been kept during the handling of core 


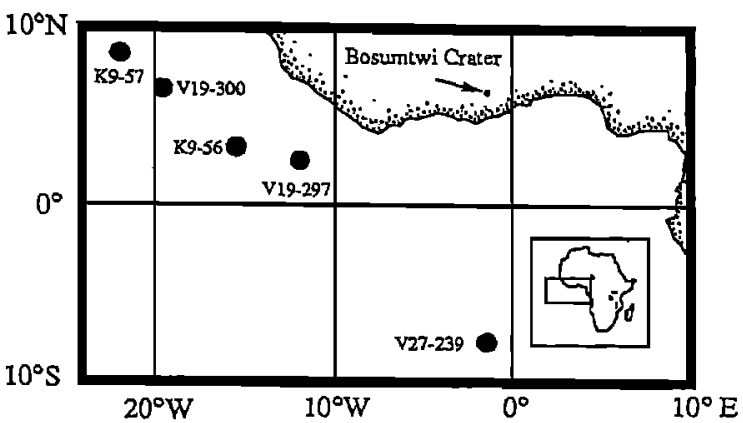

Fig. 1. Location of USNS Kane (K) and R/V Vema (V) cores reported to contain Ivory Coast microtektites and the associated Bosumtwi impact crater in Ghana.

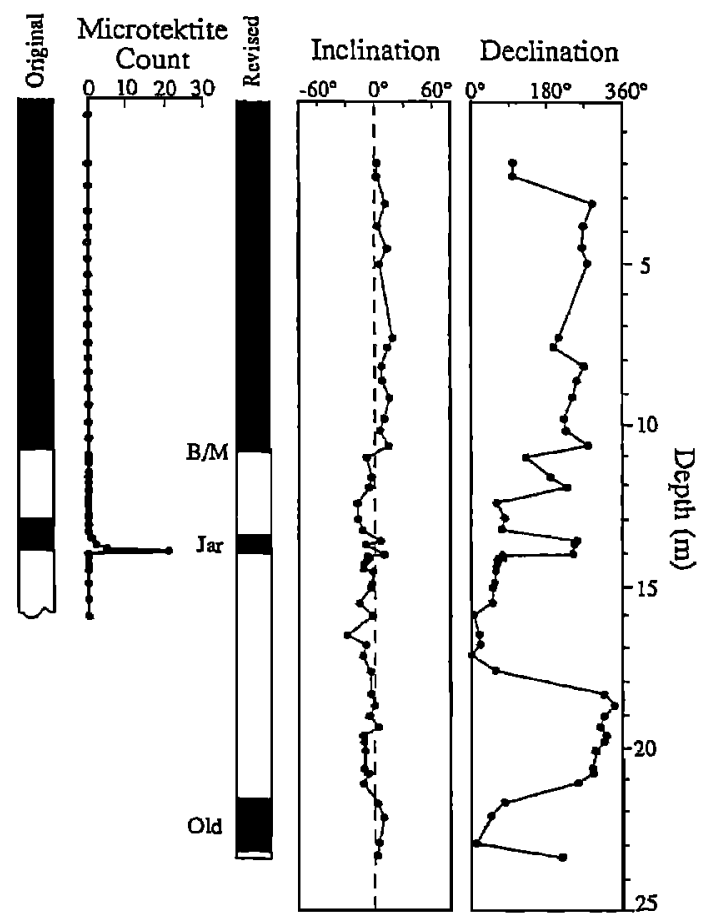

Fig. 2. Comparison of revised magnetic polarity stratigraphy of core K9-57 with the original polarity stratigraphy and microtektite abundance profiles reported by Glass et al. (1979) and Glass and Zwart (1979). Note that a core break exists near $3 \mathrm{~m}$ and so the apparent declination shift at this level is likely an artifact caused by the interchange of split core halves. The apparent declination shift near $18 \mathrm{~m}$ reflects only the gradual rotation of declination throughout the core. Black indicates normal polarity; white reverse polarity. B/M: Brunhes-Matuyama boundary (0.73 Ma); Jar: Jaramillo subchronozone (0.90 - $0.97 \mathrm{Ma})$; Old: Olduvai subchronozone (1.67 - $1.87 \mathrm{Ma})$.

K9-57. In particular, the declination shift near $300 \mathrm{~cm}$, which coincides with a core tray break and lacks a corresponding change in sign of inclination, probably reflects an intemal misorientation. We presume also that some disturbance of the sediment near $1200 \mathrm{~cm}$ has perturbed the declination record there and we place the actual reversal boundary at $1086 \mathrm{~cm}$, where there is a corresponding change in sign of inclination.

The paleomagnetic data allowed us to locate the various magnetostratigraphic boundaries, and in particular the boundaries of the Jaramillo subchronozone (Figure 4). In both cores K9-57 and V29-239 the Jaramillo boundaries did not fall near any problematic core pipe or tray breaks. We define magnetostratigraphic boundary depths as the mean depth between samples that clearly bracket the reversal, and give the uncertainty in the stratigraphic position of a reversal boundary from the depth range of the bracketing samples (Table 1). In large part, the original magnetostratigraphy is reproduced by our results; however, we have refined the placement of the top of the Jaramillo in core K9-57 and have also identified the base of the Jaramillo in core V27-239 where it was not previously determined.

The revised magnetostratigraphy shows the Jaramillo subchronozone to be only about half as thick in $\mathrm{K} 9-57$ as previously described (some $60 \mathrm{~cm}$ rather than $100 \mathrm{~cm}$ ): the top of the Jaramillo is relocated to $1345 \mathrm{~cm}$, while the base remains at $1406 \mathrm{~cm}$, essentially reproducing the placement of this boundary by Glass and Zwart (1979) at $1400 \mathrm{~cm}$. Note that the base of the Jaramillo in core K9-57 falls just 14 centimeters below the microtektite peak at $1392 \mathrm{~cm}$. We find the

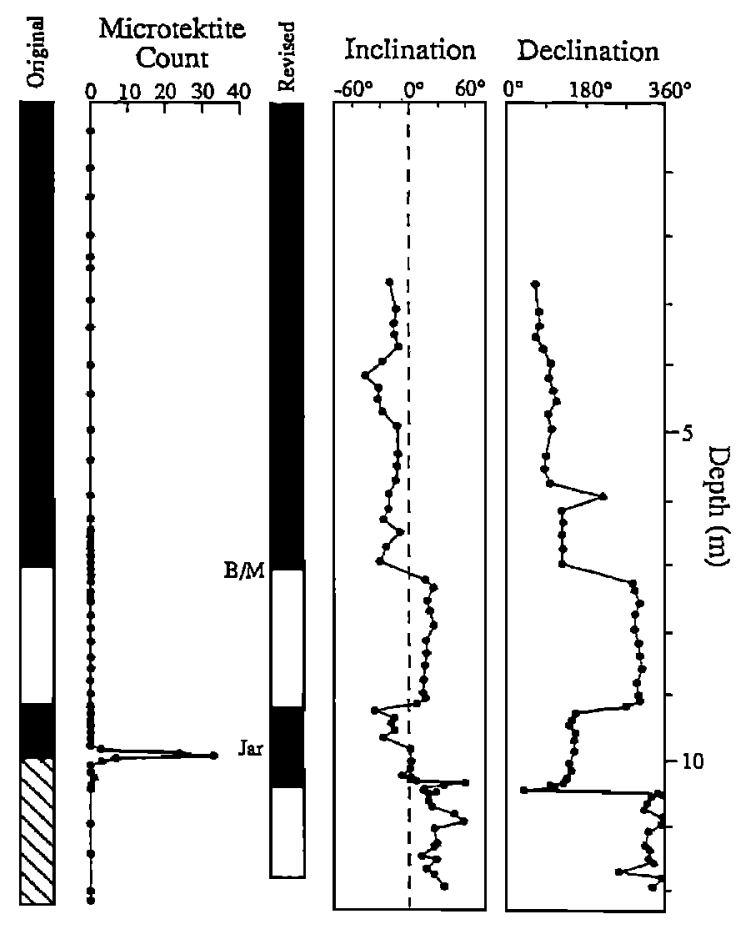

Fig. 3. Comparison of revised magnetic polarity stratigraphy of core V27-239 with the original polarity stratigraphy and microtektite abundance profiles reported by Glass et al. (1979) and Glass and Zwart (1979). The top $2.5 \mathrm{~m}$, although not resampled, are presumed to be normal polarity on the basis of the original paleomagnetic data. Conventions as in Figure 2; hachures show where no interpretation was made originally.

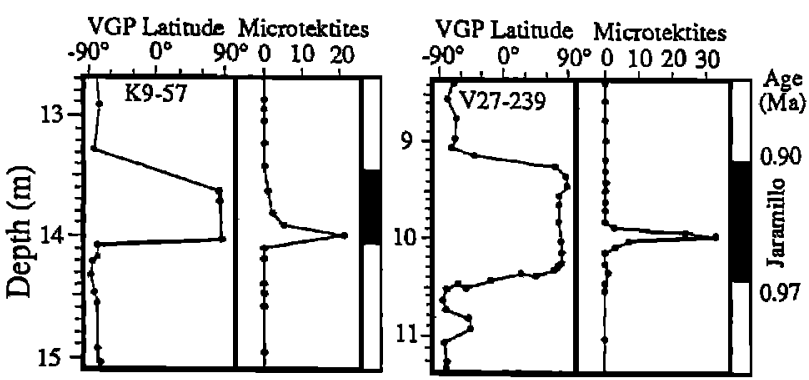

Fig. 4. Stratigraphic position of microtektites within the normal polarity Jaramillo subchronozones in cores K9-57 and V27-239. Virtual geomagnetic pole (VGP) latitude is computed assuming the mean declination over plotted range is $0^{\circ}$ (for normal polarity) or $180^{\circ}$ (for reverse polarity). 
Table 1. Magnetostratigraphic boundaries.

\begin{tabular}{lccc}
\hline \multicolumn{1}{c}{ Boundary } & $\begin{array}{c}\text { Age } \\
\text { (Ma) }\end{array}$ & $\begin{array}{c}K 9-57 \\
\text { Depth } \\
\text { (cm) }\end{array}$ & $\begin{array}{c}\text { V27-239 } \\
\text { Depth } \\
\text { (cm) }\end{array}$ \\
\hline $\begin{array}{l}\text { Brunhes/Matuyama } \\
\text { Jaramillo termination }\end{array}$ & 0.73 & $1086 \pm 18$ & $0711 \pm 14$ \\
& 0.90 & $1345 \pm 18$ & $0921 \pm 06$ \\
$\begin{array}{l}\text { Jaramillo onset } \\
\text { Olduvai termination } \\
\text { Olduvai onset }\end{array}$ & 0.97 & $1406 \pm 03$ & $1042 \pm 05$ \\
& 1.67 & $2143 \pm 30$ & $*$ \\
& 1.87 & $2315 \pm 18$ & $*$ \\
\hline
\end{tabular}

* Not penetrated by core.

top of the Jaramillo in core V27-239 at $921 \mathrm{~cm}$, confirming the $920 \mathrm{~cm}$ level given by Glass and Zwart (1979), but we are also able to identify the base of the Jaramillo in this core at $1042 \mathrm{~cm}, 46 \mathrm{~cm}$ below the microtektite peak at $996 \mathrm{~cm}$.

\section{Discussion of Results}

\section{Post-Depositional Processes}

In order to assess the timing of the reversal and impact events, we must first consider the post-depositional processes that may have affected both the microtektite and magnetic polarity records: bioturbation and post-depositional magnetization acquisition. One expects a particulate abundance peak to be depressed by an amount equal to, at most, the depth of mixing; in deep-sea sediments this homogenization depth is thought to be about $8 \mathrm{~cm}$ (e.g., Peng et al., 1979). The post-depositional acquisition of magnetization in deep-sea sediments will be similarly depressed several centimeters by bioturbation; however, it also appears that the sediments must be partially dewatered through compaction before the magnetization becomes permanently acquired (Verosub, 1977). This magnetization lock-in may occur some 10's of centimeters below the sediment-water interface, although no rigorous theory to predict the exact lock-in depth is available.

In a recent study of deep-sea sediments containing Australasian microtektites, Burms (1989) has documented the variation in lock-in depth by comparing the microtektite horizon to the level of the Matuyama to Brunhes boundary in 19 of the cores he studied. Burns concluded that sedimentation rate strongly influences the depth of magnetization acquisition and proposed a model to predict the offset between a reversal in magnetization and a stratigraphic marker horizon. The model predicted that the Matuyama to Brunhes polarity transition most likely occurred about $12 \mathrm{kY}$ after the Australasian microtekrite event and attributed the finding of microtektites above the reversal to depression of magnetization acquisition in the lower sedimentation rate cores.

We can use these results, derived from the Australasian tektite occurrence, to examine the record from the Ivory Coast strewnfield. In particular, we can test whether the stratigraphic data from the Ivory Coast is consistent with the onset of the Jaramillo chron occurring several thousand years after the microtektite event. To do this, we compare the difference in stratigraphic position between the the base of the Jaramillo subchronozone and the Ivory Coast microtektite horizon in the 2 cores we studied with the analogous Australasian results from Bums (1989) (Figure 5). Note that we follow Bums's (1989) method for determining stratigraphic level from the mean of the microtektite distribution.

The results from core K9-57 appear reasonably consistent with the Australasian offset data. That is, had the tektite event preceded the reversal by some $12 \mathrm{kY}$, the small $(17 \mathrm{~cm})$ offset between the mean microtektite horizon and the reversal

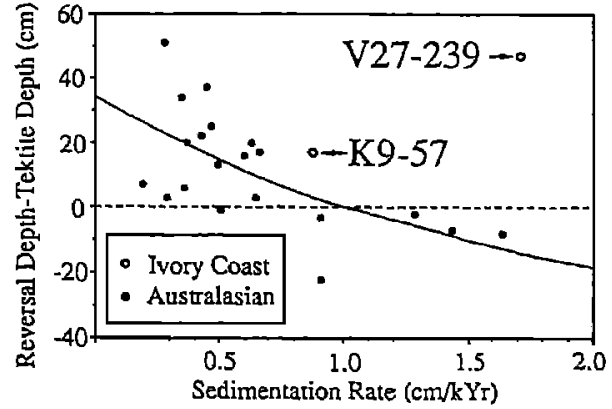

Fig. 5. Offset between polarity reversal boundary and microtektite horizon in cores containing Ivory Coast and Australasian microtektites as a function of sedimentation rate. Australasian results are from Burns (1989). Solid line indicates offset predicted on the basis of Bums's model: offset $=\mathrm{w} \Delta \mathrm{t}+\mathrm{ne}-\mathrm{w}(\Delta \mathrm{t}=-11.8 \mathrm{kY} ; \mathrm{n}=34.3 \mathrm{~cm} ; \mathrm{w}=$ sedimentation rate in $\mathrm{cm} / \mathrm{kY}$ ).

boundary would not be far from the expected offset (the prediction of Burns's model is $3 \mathrm{~cm}$ ). However, the results from core V27-239 clearly depart from the trend of the Australasian data. In the Australasian data set, lock-in depths exceeding $20 \mathrm{~cm}$ are rarely seen and only for cores with sedimentation rates less than $0.5 \mathrm{~cm} / \mathrm{kY}$. The average sedimentation rate over the Jaramillo in core V27-239 is 1.7 $\mathrm{cm} / \mathrm{kY}$; thus the $47 \mathrm{~cm}$ offset appears too large to be explained by depression of magnetization lock-in. Indeed, the position of the microtektite horizon is $61 \mathrm{~cm}$ above the prediction of Burns's model (which, at this sedimentation rate, gives an expected offset of $-14 \mathrm{~cm}$ ).

At face value, the record from core $\mathrm{K} 9-57$ alone might indicate that the reversal and tektite events were nearsimultaneous events, whereas the record from core V27-239 alone would clearly indicate that the onset of the Jaramillo preceded the impact. Because significant hiatuses are often found even in relatively continuous deep-sea sediment sequences, gaps representing 10's of thousands of years may be quite common. The effect of such gaps would be to bring diachronous events artificially into closer stratigraphic agreement. We propose that the nearer stratigraphic coincidence seen in K9-57 (Jaramillo sedimentation rate $=0.9$ $\mathrm{cm} / \mathrm{kY}$ ) is due to a stratigraphic gap and suggest that the higher-resolution record from V27-239 is more indicative of the true history of these events.

\section{A Date for the Ivory Coast Microtektite Event}

Published K-Ar and fission-track ages estimated for the Ivory Coast tektites, microtektites and Bosumtwi impact glasses range from about 0.9 to $1.2 \mathrm{Ma}$ (Zahringer, 1963; Gentner et al., 1967, 1970; Durrani and Khan, 1971; Koeberl et al., 1989). These results are largely within the range of the Jaramillo subchron (0.97 to $0.90 \mathrm{Ma}$; Mankinen et al., 1980), but do not in themselves link the tektite event to a specific geomagnetic polarity reversal. Using magnetostratigraphy, however, we can offer a more precise age for the Ivory Coast microtektite event based on the revised results from core V27239. In this core the microtektite horizon is found within the Jaramillo subchronozone, about $1 / 3$ of the distance from the base to the top. Taking the simplest assumption of a constant sedimentation rate over the Jaramillo subchron, we estimate that the microtektites were deposited at about 0.94 Ma some 30 $\mathrm{kY}$ after the onset and some $40 \mathrm{kY}$ before the termination of the Jaramillo suchron. 


\section{Impacts and Reversals}

Muller and Morris (1986, 1989) offered several lines of evidence from the geologic record that appeared to show the common coincidence of impacts and geomagnetic reversals, in support of their mechanism for changes of geomagnetic polarity. One of these pieces of evidence, the close correspondence of the Australasian microtektites with the Matuyama to Brunhes transition, was confirmed by Burns (1989); however, the Ivory Coast tektite occurrence no longer shows the supposed correlation particularly well.

Muller and Morris (1986) also argued that the formation of the Ries impact crater of West Germany and associated Moldavite tektites of Czechoslovakia (Pohl et al., 1977) coincided with a geomagnetic reversal at about $15 \mathrm{Ma}$. This conclusion was based on paleomagnetic data from a borehole by Pohl $(1977 ; 1978)$. The polarity interpretation of Pohl $(1977 ; 1978)$ shows the reversed polarity melt rocks to be overlain by pelitic lake sediments of normal polarity and was taken to demonstrate that a reversal occurred between the time of impact and the start of lake sedimentation.

We suggest that the paleomagnetic data from Pohl (1977; 1978) may not adequately record the geomagnetic history following the Ries cratering event. Although Pohl's (1977; 1978) data show that the pelitic lake sediments deposited directly above the Ries impact melts give dominantly positive inclinations (normal polarity), the directions show large scatter, even after alternating field demagnetization, with many samples having steep negative inclinations (indicating reverse polarity). A reasonable and testable alternative interpretation of these paleomagnetic data is that the lake sediments have a reverse polarity primary direction that is highly contaminated by a present-day (i.e., normal polarity) overprint.

Although Glass et al. (1979) stated that 3 impact-related tektite occurrences (Australasian, Ivory Coast and Moldavite/Ries) may have been associated with reversals of Earth's magnetic field, we submit that the coincidence of two of these events (Ivory Coast and Moldavite/Ries) with polarity reversals has not been clearly demonstrated. Moreover, the well-studied Cretaceous-Tertiary boundary, which may mark a large impact event (Alvarez et al., 1980) also does not coincide with a polarity reversal (Lowrie and Alvarez, 1977; Berggren et al., 1985). Thus the common association of impacts and geomagnetic reversals suggested by Muller and Morris (1986, 1989) may not be so well supported by the geologic record as originally supposed.

Acknowledgements. We thank Billy Glass for providing us with the original microtektite counts and Fred Bowles for his assistance during our sampling of core $\mathrm{K} 9-57$. We appreciate also the thoughtful comments provided by Peter deMenocal, William Ruddiman and Carlo Laj. This work was carried out under the US National Science Foundation Grant No. OCE87-16672. Lamont-Doherty Geological Observatory contribution \#4558.

\section{References}

Alvarez, L. W. et al., Extraterrestrial cause for the CretaceousTertiary extinction, Science, 208, 1095-1108, 1980.

Berggren, W. A. et al., Paleogene geochronology and chronostratigraphy, in The Chronology of the Geological Record, N. J. Snelling (ed.), The Geological Society Mem. No. 10., pp. 141-195, Blackwell Scientific, 1985.

Bums, C. A., Timing between a large impact and a geomagnetic reversal and the depth of NRM acquisition in deep-sea sediments, in Geomagnetism and Paleomagnetism, F. J. Lowes (ed.), pp. 253-261, Kluwer Academic Publishers, Boston, 1989.

Clement, B. M., and D. V. Kent, Short polarity intervals within the Matuyama: transitional field records from hydraulic piston cored sediments from the North Atlantic, Ear. Plan. Sci. Lett., 81, 253-264, 1986/87.
Cohen, A. J., Asteroid- or comet-impact hypothesis of tektite origin: the Moldavite strewn-fields, in Tektites, J. A. O'Keefe (ed.), pp. 189-211, Univ. of Chicago Press, Chicago, 1963.

Durrani, S. A., and H. A. Khan, Ivory Coast microtektites: fission track age and geomagnetic reversals, Nature, 232, 320-323, 1971.

Gentner, W. et al., New K-Ar and fission track ages of impact glasses and tektites, Ear. Plan. Sci. Lett. 2, 83-86, 1967.

Gentner, W. et al., Fission track ages and ages of deposition of deep-sea microtektites, Science, I68, 359-361, 1970.

Glass, B. P., and B. C. Heezen, Tektites and geomagnetic reversals, Sci. Am., 217, 32-38, 1967.

Glass, B. P. et al., Australasian, Ivory Coast and North American tektite strewnfields: size, mass and correlation with geomagnetic reversals and other earth events, Proc. Lunar Planet. Sci. Conf. 10th, 2535-2545, 1979.

Glass, B. P., and P. A. Zwart, The Ivory Coast microtektite strewnfield: new data, Ear. Plan. Sci. Lett., 43, 336-342, 1979.

Kirschvink, J. L., The least-squares line and plane analysis of palaeomagnetic data, Geophys. J. R. Astr. Soc., 62, 699-718, 1980.

Koeberl, C. et al., Geochemistry and age of the Ivory Coast tektites, 52nd Ann. Mtg. Met. Soc. Abs., Vienna, 1989.

Lowrie, W., and W. Alvarez, Upper Cretaceous-Paleocene magnetic stratigraphy at Gubbio, Italy, $\Pi$. Upper Cretaceous magnetic stratigraphy, Bull. Geol. Soc. Amer., 88, 374-377, 1977.

Mankinen, E. A. et al., Paleomagnetism of the Clear Lake volcanics and new limits on the age of the Jaramillo normal-polarity event, USGS Prof. Pap. 1141, 67-82, 1980.

Muller, R. A., and D. E. Morris, Geomagnetic reversals from impacts on the earth, Geophys. Res. Lett., 13, 1177$1180,1986$.

Muller, R. A., and D. E. Morris, Geomagnetic reversals driven by sudden climate changes, Eos Trans. AGU, 70, $276,1989$.

Peng, T.-H. et al., Rates of benthic mixing in deep-sea sediment as determined by radioactive tracers, Quat. Res., 11, 141-149, 1979.

Pohl, J., Palaeomagnetische und gesteinsmagnetische untersuchungen an den kemen der forschungsbohrung Noerdlingen 1973, Geol. Bavarica, 75, 329-348, 1977.

Pohl, J., Evidence for the coincidence of a geomagnetic reversal with the Ries impact event, in Proc. 41st Mtg. Met. Soc., p. 600, Sudbury, Canada, 1978.

Pohl, J. et al., The Ries impact crater, in Impact and Explosion Cratering, D. J. Roddy and R. B. Merrill (eds.), pp. 343-404, Pergamon Press, New York, 1977.

Shaw, H. F., and G. J. Wasserburg, Age and provenance of the target materials for tekrites and possible impactities as inferred from Sm-Nd and Rb-Sr systematics, Ear. Plan. Sci. Lett., 60, 155-177, 1982.

Verosub, K. L., Depositional and postdepositional processes in the magnetization of sediments, Rev. Geophys., 15, 129-142, 1977.

Zahringer, J., K-Ar measurements of tektites, in Radioactive Dating, 289-305, International Atomic Energy Agency, Vienna, 1963.

D. V. Kent, Lamont-Doherty Geological Observatory and Department of Geological Sciences, Columbia University, Palisades, NY 10964.

D. A. Schneider, Centre des Faibles Radioactivités, Laboratoire Mixte CNRS-CEA, Avenue de la Terrasse, 91198 Gif-sur-Yvette Cedex, France.

(Received August 17, 1989; accepted November 14,1989 ) 